\title{
Oil production prediction with neural network method
}

\author{
Haohan Liu, Wei Li, Songlin Zhang \\ Sichuan College of Architectural Technology \\ Deyang, China, 618000 \\ e-mail:tsinghua616@163.com
}

\begin{abstract}
Many kinds of method can be used to predict oil production, and the neural network method is one of the most basic methods to predict oil production. In this study a modified neural network method is proposed to predict oil production in oil field. A fuzzy cluster analysis is introduced to determine the major influencing factors and obtain nondimensional data; a proper kernel function of the neural network structure is chosen to establish the relational expression of site variables and fit the relational expression of weight. A new predicting method based on the cluster analysis is proposed to predict the oil production. Good predicting results are obtained by introducing this new method to the Cong-D block of certain block faulted oilfield of China.
\end{abstract}

Keywords-correlation degree analysis; neural network; prediction

\section{INTRODUCTION}

In 1985, Rumelhart[1] proposed the Back propagation learning Algorithm and established the BP network model. Then, the neural network technology has been widely used. The characteristics of this BP network model are famous for its exact structure, good controllability and so on. In 1989, Robert Hecht-Nielsen[2]proved that a continuous function in any closed interval can be approximated by a three layer network structure. Since the beginning of this century, neural network technology is widely used in the petroleum industry [3,4,5,6]. Salari et al (2008)[7] used the neural network to model the oxidative desulfurization of fuel oil; Ozbayoglu et al (2009)[8]used artificial neural networks to estimate flow patterns and frictional pressure losses of two-phase fluids in horizontal well bores; Khandelwal et al (2010)[9]consider the artificial neural networks as a valuable tool for well log interpretation; ZareNezhad, et al (2011)[10] used the artificial neural network model to design the wellhead chokes in gas condensate production fields; Al-Anazi et al (2011)[11]establish an artificial neural network system to predict the compressibility factor of sour and natural gas. References[12,13,14] represent the latest research and application area of neutral networks in the petroleum industry. In this paper, we aim to establish a new predicting method with neural network to predict oil production in certain oil field in China.

\section{CONFIRMATION OF MAIN INFLUENCE FACTORS}

Using correlation degree analysis method to determine the major influencing factors takes the following steps: Step1. Determination of dependent variable and independent variable. Select certain indices to be dependent variables and the others to be independent variables. Let time sequence of dependent variables be a reference sequence, denoted by $x_{0}^{\prime}$ and the time sequence of independent variables be a comparison sequence, denoted by $x_{i}^{\prime}(i=1,2,3, \cdots, N)$.

Step 2. Non-dimensional variable sequence

$$
x_{i}(k)=\frac{x_{i}^{\prime}(k)}{\frac{1}{N} \sum_{k=1}^{N} x_{i}^{\prime}(k)},\left(\begin{array}{c}
i=0,1,2, \cdots, n \\
k=1,2, \cdots, N
\end{array}\right)
$$

Step 3. Calculation of correlation coefficient

$$
\begin{aligned}
& r_{0 m}(k)=\frac{\min _{m} \min _{k}\left|x_{m}(k)-x_{0}(k)\right|+\rho \times \max _{m} \max _{k}\left|x_{m}(k)-x_{0}(k)\right|}{\left|x_{m}(k)-x_{0}(k)\right|+\rho \times \max _{m} \max _{k}\left|x_{m}(k)-x_{0}(k)\right|}, \\
& m=1,2, \cdots, n
\end{aligned}
$$

Where $r_{0 m}(k)$ is the correlation coefficient between $x_{m}$ and $x_{0}$ in time $k$; parameter $\rho$ is the resolution ratio, valued in $(0,1)$. The smaller $\rho$ is, the smaller the correlation coefficient becomes. In general, $\rho$ is valued from 0.1 to 0.5 .

Step 4. Calculation of correlation degree

Using the formula

$$
\begin{aligned}
& r_{0 m}=\frac{1}{N} \sum_{k=1}^{N} r_{0 m}(k), \\
& m=1,2, \cdots, n, k=1,2, \cdots, N
\end{aligned}
$$

to calculate the correlation degree between independent variables and dependent variables. The major influencing factors are thus well established with correlation degree analysis. 


\section{NEURAL NETWORK PREDICTION OF OIL PRODUCTION}

\section{A. Neural network structure}

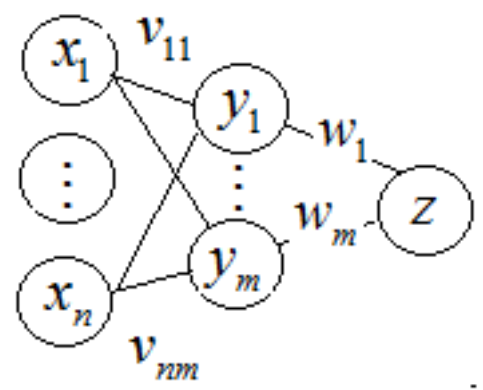

Figure 1. neural network structure

Given $\mathrm{N}$ pairs of pattern vectors, denoted by $\quad\left\{x_{1}{ }^{i}, x_{2}{ }^{i}, \cdots, x_{n}{ }^{i} ; z_{i}\right\}, i=1,2, \cdots N \quad$, where $x_{1}{ }^{i}, x_{2}{ }^{i}, \cdots, x_{n}{ }^{i}, z_{i}$ are given dimensionless values. The weighting coefficient of network are $v=\left(v_{11}, v_{12}, \cdots, v_{m n}\right)$ and $w=\left(w_{1}, w_{2}, \cdots, w_{n}\right)$. The output of the second layer of pattern vectors are $y^{s}(v)$, where

$y^{s}(w)=\left(y^{s}{ }_{1}(v), y^{s}{ }_{2}(v), \cdots, y^{s}{ }_{m}(v)\right), s=1,2, \cdots, N$.

Using the rule in step 2 to proceed normalization of influencing factors to confirm the non-dimensional variable sequence.

\section{B. New prediction with neural network model}

From the network structure, we expect to get the final value $z$, so we need to determine the value of relational expression of weight. To determine that value, the equation groups of weighting coefficients $(v, w)$ should be established. Here, the penalty function is $f(x)=\frac{e^{x}}{1+e^{x}}$. Then we get the related output expression of inverse neural network: $y_{i}=\sum_{i=1}^{n} v_{j i} f\left(x_{i}\right), j=1,2, \cdots, m, z=\sum_{i=1}^{m} w_{i} f\left(y_{i}\right)$. Thus we get the following equation groups:

$$
z^{s}=\sum_{i=1}^{m} w_{i} f\left(\sum_{i=1}^{n} v_{j i} f\left(x_{i}^{s}\right)\right), j=1,2, \cdots, m, s=1,2, \cdots N
$$

After training by neural network algorithm, the wighting value vector $(v, w)$ can be confirmed, then given a new influencing factor, a new out put value of oil production can be achieved.

\section{APPLICATION}

By introducing this new model of neural network to Cong-D block of certain block faulted oilfield of China, the monthly oil production of this block can be predicted. Through correlation degree analysis, we define the major oil production influencing factors, including block liquid producing capacity, block oil producing capacity, block filtration capacity, block water absorbing capacity and block pressure support level. Given the data table in the year 2009, see table 1.

TABLE I. DATA OF CONG-D BLOCK OF CERTAIN BLOCK FAULTED OILFIELD

\begin{tabular}{|c|c|c|c|c|c|c|}
\hline Item & \multicolumn{5}{|c|}{ Control variable } & \multirow{2}{*}{$\begin{array}{c}\text { Input } \\
\text { variable } \\
\\
\text { Block } \\
\text { actual } \\
\text { monthly } \\
\text { oil } \\
\text { productio } \\
\text { n }\end{array}$} \\
\hline $\begin{array}{c}\text { Tim } \\
\text { e(ye } \\
\text { ar/m } \\
\text { onth } \\
\text { ) }\end{array}$ & $\begin{array}{c}\text { Bloc } \\
\mathbf{k} \\
\text { liqui } \\
\mathbf{d} \\
\text { prod } \\
\text { ucing } \\
\text { capa } \\
\text { city }\end{array}$ & $\begin{array}{c}\text { Bloc } \\
\text { k oil } \\
\text { pro } \\
\text { duci } \\
\text { ng } \\
\text { capa } \\
\text { city }\end{array}$ & $\begin{array}{c}\text { Block } \\
\text { filtrati } \\
\text { on } \\
\text { capacit } \\
y\end{array}$ & $\begin{array}{c}\text { Block } \\
\text { water } \\
\text { absorbin } \\
\text { g } \\
\text { capacity }\end{array}$ & $\begin{array}{c}\text { Block } \\
\text { pressu } \\
\text { re } \\
\text { suppor } \\
\text { t level }\end{array}$ & \\
\hline $\begin{array}{c}2012 \\
.2\end{array}$ & 0.214 & $\begin{array}{c}0.13 \\
58\end{array}$ & $\begin{array}{c}370.03 \\
3\end{array}$ & 0.7667 & 1.9129 & 1730 \\
\hline $\begin{array}{c}2012 \\
.3\end{array}$ & 0.214 & $\begin{array}{c}0.13 \\
59\end{array}$ & $\begin{array}{c}445.64 \\
36\end{array}$ & 0.7711 & 1.6793 & 1919 \\
\hline $\begin{array}{c}2012 \\
.4\end{array}$ & $\begin{array}{c}0.213 \\
9\end{array}$ & $\begin{array}{c}0.13 \\
87\end{array}$ & $\begin{array}{c}398.78 \\
79\end{array}$ & 0.7749 & 1.8699 & 1680 \\
\hline $\begin{array}{c}2012 \\
.5\end{array}$ & 0.214 & $\begin{array}{c}0.13 \\
87\end{array}$ & $\begin{array}{c}389.59 \\
12\end{array}$ & 0.7777 & 1.3752 & 1975 \\
\hline $\begin{array}{c}2012 \\
.6\end{array}$ & 0.214 & $\begin{array}{c}0.13 \\
86\end{array}$ & $\begin{array}{c}355.61 \\
16\end{array}$ & 0.7840 & 1.5737 & 1789 \\
\hline
\end{tabular}

TABLE II. DATA OF NORMALIZATION

\begin{tabular}{|c|c|c|c|c|c|c|}
\hline $\begin{array}{c}\text { Ite } \\
\text { m }\end{array}$ & \multicolumn{5}{|c|}{ Control variable } & Input \\
\hline$\underset{\mathrm{e}}{\mathrm{Tim}}$ & $\begin{array}{c}\text { Block } \\
\text { liquid } \\
\text { produc } \\
\text { ing } \\
\text { capacit } \\
y\end{array}$ & $\begin{array}{c}\text { Block oil } \\
\text { produci } \\
\text { ng } \\
\text { capacity }\end{array}$ & $\begin{array}{c}\text { Block } \\
\text { filtratio } \\
\quad \mathbf{n} \\
\text { capacit } \\
\mathbf{y}\end{array}$ & $\begin{array}{c}\text { Bloc } \\
\mathbf{k} \\
\text { wate } \\
\mathbf{r} \\
\text { abso } \\
\text { rbing } \\
\text { capa } \\
\text { city }\end{array}$ & $\begin{array}{c}\text { Block } \\
\text { pressure } \\
\text { support } \\
\text { level }\end{array}$ & $\begin{array}{c}\text { Block } \\
\text { actual } \\
\text { oil } \\
\text { producti } \\
\text { on }\end{array}$ \\
\hline $\begin{array}{l}201 \\
2.2\end{array}$ & $1-10^{-5}$ & $10^{-5}$ & 0.16018 & $10^{-5}$ & $1-10^{-5}$ & 0.16949 \\
\hline $\begin{array}{c}201 \\
2.3\end{array}$ & $1-10^{-5}$ & 0.034483 & $1-10^{-5}$ & $\begin{array}{c}0.254 \\
34\end{array}$ & 0.56556 & 0.81017 \\
\hline $\begin{array}{l}201 \\
2.4\end{array}$ & $10^{-5}$ & $1-10^{-5}$ & 0.47957 & $\begin{array}{c}0.473 \\
99\end{array}$ & 0.92003 & $10^{-5}$ \\
\hline $\begin{array}{l}201 \\
2.5\end{array}$ & $1-10^{-5}$ & $1-10^{-5}$ & 0.37742 & $\begin{array}{c}0.635 \\
84\end{array}$ & $10^{-5}$ & $1-10^{-5}$ \\
\hline $\begin{array}{c}201 \\
2.6\end{array}$ & $1-10^{-5}$ & 0.96552 & $10^{-5}$ & $1-10$ & 0.36916 & 0.36949 \\
\hline
\end{tabular}

Where $x_{1}, x_{2}, x_{3}, x_{4}, x_{5}$ are block liquid producing capacity, block oil producing capacity, block filtration capacity, block water absorbing capacity and block pressure support level, separately. After using this new predicting model, we get the weighting value vector and after giving a new value of input vector, we predict the monthly oil production, from February to July, see table 3: 
TABLE III. PREDICTING VALUE OF MONTHLY OIL PRODUCTION

\begin{tabular}{|c|c|c|c|}
\hline $\begin{array}{c}\text { Time/ } \\
\text { month }\end{array}$ & $\begin{array}{c}\text { Real value of oil } \\
\text { production/m3 }\end{array}$ & $\begin{array}{c}\text { Predicting } \\
\text { value oil } \\
\text { production/ } \\
\text { m }\end{array}$ & $\begin{array}{c}\text { Predicting } \\
\text { accuracy, \% }\end{array}$ \\
\hline 2 & 1730 & 1591.6 & 92 \\
\hline 3 & 1919 & 1823.9 & 95 \\
\hline 4 & 1680 & 1714.4 & 98 \\
\hline 5 & 1975 & 1955.3 & 99 \\
\hline 6 & 1789 & 1698.7 & 95 \\
\hline 7 & $?$ & 1818.2 & The average \\
accuracy is 95.8 \\
\hline
\end{tabular}

Note: when the error sum of squares is large, we can study the selection of data, study the upper and lower bound, and even the related economical factors, to lessen the error sum of square and make the new feasible solution be nearer to the real solution. By introducing the controlling value of block liquid producing capacity, block oil producing capacity, block filtration capacity, block water absorbing capacity and block pressure support level to the neural network structure and predicting the oil production, we get the following figures:

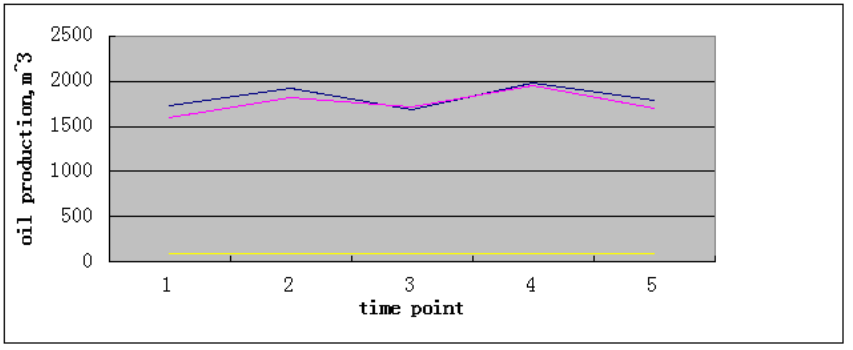

Figure 2. comparison of real oil production value and predicting oil production value.

In figure 2 , the blue point line is the real value of oil production and the red point line is the predicting value, the yellow point is the month point.

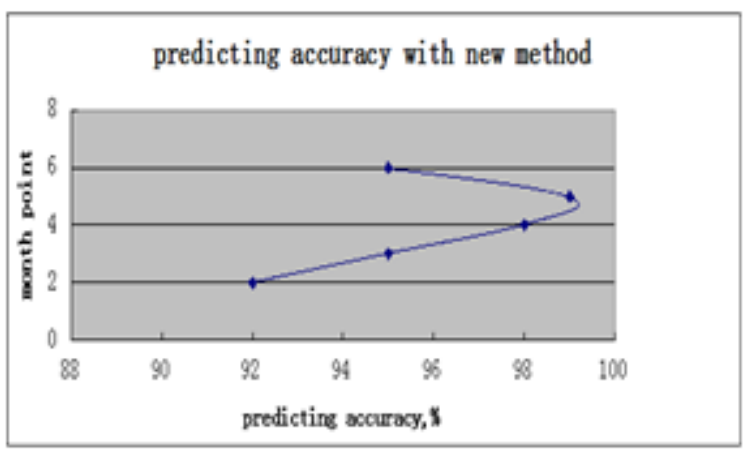

Figure 3. predictive errors of oil production

Figure 2 and 3 show that the predicting value of oil production is close to the real value of oil production, it is, by using the above-mentioned method to predict the oil production is feasible and correct.

\section{CONCLUSIONS}

(1) In this study correlation degree analysis was introduced to determine the main influencing factors and new penalty function were introduced to confirm the weighting expression;

(2) A new oil production prediction method is proposed ;

(3) Good predicting results were achieved by using this new theory to Cong-D block of certain block faulted oilfield.

\section{REFERENCES}

[1] Rumelhart, D. E, and McClelland, J. L. "Learning internal representations by error propagation. Cambridge", MA: MIT Press, 1986, pp:317-362.

[2] Hecht-Nielsen, R. "Theory of the back propagation neural network. Proceedings of the Int. Joint Conf on Neural Networks. Washington",1989, pp.593-605.

[3] M. Stundner, GmbH, J. S. Al, Saudi Aramco. "How data-driven modeling methods like neural networks can help to integrate different types of data into reservoir management", 2001.

[4] S.M. AI-Fattah,Saudi Aramco, R.A. "Startzman. Prediction natural gas production using artificial neural network",2001.

[5] C.Alimonti, G. Falcone. Integration of multiphase flow metering, neural networks, and fuzzy logic in field performance monitoring,2004.

[6] A.Saeedi,K.V.Camarda,J.T.Liang. "Using neural networks for candidate selection and well proformance prediction in water-shutoff treatments using polymer gels-a field-case study",2006.

[7] Salari, D., and Rostamizadeh, K. "Oxidative desulfurization of fuel oil: modeling based on artificial neural network. Petroleum Science and Technology", 2008, vol 26, pp. 382-397

[8] Ozbayoglu, E. M., and Ozbayoglu, M. A. "Estimating flow patterns and frictional pressure losses of two-phase fluids in horizontal wellbores using artificial neural networks. Petroleum Science and Technology", 2009, vol.27, pp. 135 - 149.

[9] Khandelwal, M., and Singh, T. N. "Artificial neural networks as a valuable tool for well log interpretation. Petroleum Science and Technology". 2010, vol.28.14,pp.1381-1393.

[10] ZareNezhad, B., and Aminian, A. "An artificial neural network model for design of wellhead chokes in gas condensate production fields. Petroleum Science and Technology",2011, vol. 29.6,pp.579 587.

[11] Al-Anazi B.D., Pazuki.G.R., and et al. "The prediction of the compressibility factor of sour and natural gas by an artificial neural network system". Petroleum science and technology,2011,vol. 29(4),pp.325 -336.

[12] Olivares,C.Escalona,E.Gimenez. "Production monitoring using monitoring using artificail intelligence", APLT Asset,2012.

[13] César Bravo et al. "State of the art of artificial intelligence and predictive analytics in the E\&P industry: a technology survey", 2012.

[14] Peng Song et al. "Coiled tubing working life prediction based on BP algorithm of artificial neural network",2012. 